\title{
Free and Enzymatically Hydrolysed Volatile Compounds of Sweet Wines from Malvasia and Muscat Grapes (Vitis vinifera L.) Grown in Sardinia
}

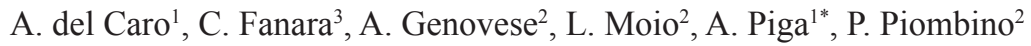 \\ (1) Dipartimento di Agraria, Università degli Studi di Sassari, Viale Italia 39/A, 07100 Sassari, Italy \\ (2) Dipartimento di Scienza degli Alimenti, Università degli studi di Napoli Federico II, P.co Gussone, 80055 Portici (NA), Italy \\ (3) External collaborator
}

Submitted for publication: November 2011

Accepted for publication: February 2012

Key words: free volatiles, bound volatiles, Muscat, Malvasia, Sardinia, sweet wine

\begin{abstract}
The aroma of Muscat of Sorso-Sennori and Malvasia di Bosa wines obtained from grapes grown in Sardinia was evaluated by instrumental analysis. Gas chromatography/mass spectrometry was used to identify and quantify the content of free and bound volatile compounds. The odour activity value (OAV) was also calculated. Higher alcohols and esters were quantitatively the largest group of free volatile compounds in both wines, while terpenes were the main class of bound volatiles. A total of 52 free and 26 bound volatiles were detected. Malvasia di Bosa sweet wine had a higher content of alcohols, esters and acids in comparison to Muscat of Sorso-Sennori, which was richer in some terpenes, like nerol, geraniol and geranic acid, and also in bound volatile compounds. A total of 12 compounds were above the OAV. The main aroma-active compounds of Muscat were 3-methylbutyl acetate (banana), ethyl octanoate and hexanoate (fruity), and linalool (flowery), Malvasia wine was characterised particularly by ethyl octanoate and by 3-methylbutyl acetate.
\end{abstract}

\section{INTRODUCTION}

Among all the aroma constituents, volatiles coming from grapes play an important role in the quality and typicality of wines. In this context, grape varieties can be divided into aromatic and non-aromatic: aromatic grapes have free and glycosylated volatiles (terpenes, $\mathrm{C}_{13}$-norisoprenoids), which, through hydrolysis, may generate precursors of the aromatic compounds that give the typical flavour to the wine, as in Muscat; non-aromatic grapes possess both free and glycosylated volatiles, but the free forms are at a concentration lower than their odour thresholds, thus they make a negligible contribution to the aroma characteristics of wines such as Riesling, Chardonnay, Pinot and Merlot, among others (Sefton et al., 1993; Winterhalter, 1993; Kotseridis et al., 1998; Di Stefano et al., 2000). Moreover, it is well known that, while the cultivar qualitative profile depends strictly on the cultivar, the relative amounts of each compound and thus the sensory properties are also influenced strongly by the terroir, which includes all the regional parameters such as soil, climate, viticulture managements and crop level (Fischer et al., 1999).

Sardinia has a old tradition in the wine industry and produces high-value wines from red and white grapes. Sardinia currently has 19 defined DOC areas (Denomination of Controlled Origin), one DOCG (Denomination of Controlled and Guaranteed Origin), and 15 areas of IGT (Typical Geographical Indication). The production of white wines is concentrated largely in the central and northern part of the island, while the production of red wines is concentrated mainly in the south. Two very important aromatic grapes of Sardinia are Malvasia di Bosa (MV) and Muscat of Sorso-Sennori (MS). The MV is a synonym for Malvasia di Sardegna (number 7266 in the Vitis International Variety Catalogue) and the MS is a synonym for Moscato Bianco (number 8193 in the Vitis International Variety Catalogue). These grapes are used to make sweet wines that are sold on the world market every year. Sweet wine production requires harvesting of the grapes at an overripe stage, and this results in particular sensory descriptors such as floral, thyme flower, tropical fruit, passion fruit, mango, citrus, orange peel, apricot, dried apricot, peach, marmalade, honey and caramel (Croser, 1989). MS grapes are grown in the north-west part of Sardinia, in the district of Sorso and Sennori, and their vinification gives rise to a DOC sweet wine (Moscato di Sorso-Sennori). MV grapes are grown in the central-west part of Sardinia, in the territories of Bosa, Suni, Tinnura, Flussio, Modolo and Magomadas. Dry and sweet wines are

*Corresponding author: pigaa@uniss.it [Tel/Fax: +39(0)79-229272]. The authors contributed equally to this study

Acknowledgements: We kindly acknowledge the Società Cooperativa Romangia and Zarelli Vini S.r.L., for providing us with the Muscat and Malvasia wine samples respectively 
produced from MV grapes. To our knowledge, no data are available in the literature on the aromatic composition of sweet wines obtained from these grapes grown in Sardinia.

This work therefore was aimed at characterising the free and bound volatile composition of two commercial sweet wines deriving from Muscat of Sorso-Sennori and Malvasia di Bosa.

\section{MATERIALS AND METHODS Wine samples}

Muscat (MS) was supplied by a north Sardinian cooperative wine growers' association, while Malvasia (MV) was supplied by an important Sardinian winery. The MS and MV grapes were harvested in the second half of October 2008, at 28 and $25.5{ }^{\circ}$ Brix respectively. For the MS wine, the harvested grapes were crushed and $\mathrm{SO}_{2}(5 \mathrm{~g} / 100 \mathrm{~kg})$, pectic enzyme $(3 \mathrm{~g} / 100 \mathrm{~kg})$, tannins $(15 \mathrm{~g} / 100 \mathrm{~kg})$ and ascorbic acid $(6 \mathrm{~g} / 100 \mathrm{~kg})$ were added. The must was cooled to $19^{\circ} \mathrm{C}$ and inoculation was carried out at $30 \mathrm{~g} / \mathrm{hL}$, after rehydration of the yeast (Uva ferm Ghm, Lallemand, Montreal, Canada) in warm water for $30 \mathrm{~min}$, as described by the manufacturer. Fermentation took place in stainless steel tanks at 19 to 20 ${ }^{\circ} \mathrm{C}$, and skin contact lasted until the initial sugar content had been halved. Racking was done at $8^{\circ}$ Brix residual sugar level, and fermentation was stopped by chilling to $-3{ }^{\circ} \mathrm{C}$, followed by stabilisation. Wine samples were bottled six months after winemaking.

For the MV wine, the harvested grapes were crushed and $\mathrm{SO}_{2}(5 \mathrm{~g} / 100 \mathrm{~kg})$ was added. After overnight skin contact, the must was drained and inoculation with the selected yeast (US-01, Unistrains SrL, Sassari, Italy) was carried out. Fermentation took place in stainless steel tanks at 18 to $20{ }^{\circ} \mathrm{C}$. Racking was done at $3^{\circ}$ Brix residual sugar level, and fermentation was stopped by chilling to $-3^{\circ} \mathrm{C}$, followed by stabilisation. Wine samples were bottled six months after winemaking. Samples of both wines were analysed in triplicate at the time of bottling in May 2009.

\section{Extraction and gas chromatography-mass spectrometry (GC-MS) analysis of volatiles}

Free and glycosylated volatile compounds were extracted from the wines, following the solid phase extraction methods proposed by different authors (Di Stefano et al., 1991; Mateo et al., 1997; Moio et al., 2004), with some modifications. A total of $25 \mathrm{~mL}$ of wine was diluted with an equal amount of water and added to 2 -octanol as internal standard $(125 \mu \mathrm{L}$ of a $200 \mathrm{mg} / \mathrm{L}$ methanol solution), then loaded into a previously activated 1 g C-18 cartridge (Phenomenex, Torrence, CA) and passed through at $3 \mathrm{~mL} / \mathrm{min}$. The cartridge was washed with $10 \mathrm{~mL}$ of water. The free volatile compounds were eluted with $5 \mathrm{~mL}$ of dichloromethane, then $10 \mathrm{~mL}$ of methanol was used for the recovery of the glycoconjugated fraction (bound volatiles). The dichloromethane fraction was concentrated to dryness with $\mathrm{Na}_{2} \mathrm{SO}_{4}$ and then reduced to a small volume $(\sim 100 \mu \mathrm{L})$ with nitrogen flushing.

The methanol fraction was concentrated to dryness with a rotary evaporator and dissolved again in $5 \mathrm{~mL}$ of phosphatecitrate buffer ( $\mathrm{pH}$ 5.0) containing $40 \mathrm{mg}$ of Novarom ${ }^{\mathrm{TM}}$ Blanc $\beta$-glucosidase enzyme (Novozymes, Bagsvaerd, Denmark). After $16 \mathrm{~h}$ of incubation at $40 \pm 2{ }^{\circ} \mathrm{C}, 125 \mathrm{~mL}$ of an alcoholic solution of 2-octanol was added as internal standard, the mixture containing free aglycons was loaded into a C-18 SPE cartridge, and the volatiles were extracted with $5 \mathrm{~mL}$ of dichloromethane. The extract, dried over $\mathrm{Na}_{2} \mathrm{SO}_{4}$, was concentrated under a stream of pure $\mathrm{N}_{2}(1.5 \mathrm{~L} / \mathrm{min})$ for $\mathrm{GC}$ MS analysis. Each extraction was carried out in triplicate.

GC-MS analysis was performed using a GC/MSQP2010 mass spectrometer (Shimadzu, Shimadzu Corp., Kyoto, Japan) equipped with a split/splitless injector and a DB-WAX column (60 m x 0.250 i.d., $0.25 \mu \mathrm{m}$ film thickness; J\&W Scientific Inc., Folsom, CA 95360, USA). The temperature program used was $40{ }^{\circ} \mathrm{C}$ for $5 \mathrm{~min}$, increasing by $2{ }^{\circ} \mathrm{C} / \mathrm{min}$ to $220{ }^{\circ} \mathrm{C}$, and held at maximum temperature for $20 \mathrm{~min}$. The flow of the carrier gas (He) was $1.02 \mathrm{~mL} /$ min. Injections of $1 \mu \mathrm{L}$ were performed in splitless mode while the injector port and the ion source were maintained at $250{ }^{\circ} \mathrm{C}$ and $230{ }^{\circ} \mathrm{C}$ respectively. Positive electron impact spectra were recorded at $70 \mathrm{eV}$ in the range $\mathrm{m} / \mathrm{z} 33$ to 350 . Identification of the compounds was confirmed by injection of pure standards and comparison with their retention indices and MS data reported in the literature. Compounds for which pure reference standards were not available were identified only on the basis of their retention times and MS spectra.

The quantification used gave semi-quantitative results, but in this case exact amounts were not that important because of the wide variability of the published odour threshold values (OTV) (Takeoka et al., 1989; Etievant, 1991; Guth, 1997; Ferreira et al., 2000; Vilanova \& Sieiro, 2006), as already reported by Vilanova et al. (2010). The literature OTV were used to calculate the odour activity value (OAV) of the most relevant volatiles detected by dividing the concentration detected by the OTV.

\section{Statistical analysis}

The data on the volatiles were evaluated by a one-way ANOVA (Statistica) and the wine was used as the group variable.

\section{RESULTS AND DISCUSSION \\ Free volatiles}

GC-MS allowed us to detect 52 volatile compounds, although two only in traces. We found fifteen higher alcohols, three C-6 alcohols, thirteen terpenoids, thirteen esters, three acids, two lactones, one aldehyde, one volatile phenol and one other compound (Table 1; Fig. 1). Alcohols, esters and acids were the main compounds in both wines, and are fermentative products produced by yeast metabolism during fermentation.

Terpenes are responsible for the characteristic varietal aroma of Muscat and other aromatic wines (Marais, 1983; Rapp et al., 1986; Pisarnitskii, 2001; Selli et al., 2006; Zalacain et al., 2007). Geranic acid, linalool, nerol, geraniol and $\beta$-citronellol were the most abundant terpenes in MS; terpinen 4-ol, with an OTV of 15 (Vilanova \& Sieiro, 2006) (Table 2), and 2,6-dimethyl-3,7-octadien-2,6-diol accounted for about $80 \%$ of the terpenes in $\mathrm{MV}$, which completely lacked $\beta$-citronellol and trans and cis linalool oxide. It should be highlighted that geranic acid was the main terpenoid compound found in MS, accounting for 35\% of the total terpenoid content, and as has already been found in Muscat of Frontignan grapes (Bureau et al., 2000) and, 
TABLE 1

Free volatiles $(\mu \mathrm{g} / \mathrm{L} \pm \mathrm{SD})$ detected in Muscat of Sorso-Sennori and Malvasia di Bosa sweet wines.

\begin{tabular}{|c|c|c|c|c|c|}
\hline \multirow[t]{2}{*}{ Volatile compound } & \multicolumn{2}{|c|}{ Wine } & \multirow[t]{2}{*}{ Volatile compound } & \multicolumn{2}{|c|}{ Wine } \\
\hline & Muscat & Malvasia & & Muscat & Malvasia \\
\hline C-6 Alcohols & & & Terpenes & & \\
\hline (Z)-3-Hexen-1-ol & $13 \pm 1 b^{*}$ & $45 \pm 3 a$ & (E) Linalool oxide & $30 \pm 2 \mathrm{a}$ & $\mathrm{NPb}$ \\
\hline 1-Hexanol & $1271 \pm 21 \mathrm{a}$ & $1 \_098 \pm 47 b$ & (Z) Linalool oxide & $56 \pm 2 \mathrm{a}$ & $\mathrm{NPb}$ \\
\hline (E)-3 Hexen-1-ol & $12 \pm 1 b$ & $170 \pm 3 \mathrm{a}$ & Linalool & $326 \pm 13 a$ & $42 \pm 1 b$ \\
\hline \multirow[t]{2}{*}{ Total } & $1296 \pm 22$ & $1313 \pm 59$ & Terpinen 4-ol & $11 \pm 1 b$ & $599 \pm 13 a$ \\
\hline & & & Hotrienol & $12 \pm 2 b$ & $26 \pm 2 \mathrm{a}$ \\
\hline Alcohols & & & $\alpha$-Terpineol & $114 \pm 7 \mathrm{a}$ & $52 \pm 2 b$ \\
\hline 2-Methyl-1-propanol & $1916 \pm 175 b$ & $2652 \pm 162 \mathrm{a}$ & 2,6-Dimethyl-3,7-octadien-2,6-diol & $108 \pm 1 b$ & $366 \pm 14 \mathrm{a}$ \\
\hline 1-Butanol & $99 \pm 7 \mathrm{a}$ & $50 \pm 5 b$ & Epoxylinalool I & $\mathrm{NPb}$ & $57 \pm 2 \mathrm{a}$ \\
\hline 3+2-Methyl-1-butanol & $45602 \pm 3056 \mathrm{a}$ & $52966 \pm 2250 \mathrm{a}$ & $\beta$-Citronellol & $185 \pm 1 \mathrm{a}$ & $\mathrm{NPb}$ \\
\hline 2-Methyl-3-buten-1-ol & $14 \pm 1 \mathrm{a}$ & $6 \pm 1 b$ & Nerol & $249 \pm 12 \mathrm{a}$ & $25 \pm 2 b$ \\
\hline 1-Pentanol & $164 \pm 1 \mathrm{a}$ & $47 \pm 2 b$ & Geraniol & $229 \pm 2 \mathrm{a}$ & $25 \pm 2 b$ \\
\hline 4-Methyl-1-pentanol & $17 \pm 1 b$ & $47 \pm 1 \mathrm{a}$ & 2,6-Dimethyl-1,7-octadien-3,6-diol & $49 \pm 6 a$ & trb \\
\hline 3-Methyl-1-pentanol & $33 \pm 1 b$ & $45 \pm 1 \mathrm{a}$ & Geranic acid & $689 \pm 40 \mathrm{a}$ & $23 \pm 3 b$ \\
\hline 2-Octanol & $17 \pm 2 \mathrm{a}$ & $17 \pm 1 \mathrm{a}$ & Total & $2067 \pm 102$ & $1227 \pm 32$ \\
\hline 1-Octen-3-ol & $79 \pm 4 a$ & $7 \pm 1 b$ & & & \\
\hline 1-Heptanol & $338 \pm 50 \mathrm{a}$ & $40 \pm 9 b$ & Acids & & \\
\hline 2-Ethyl-1-hexanol & $17 \pm 2 \mathrm{a}$ & $17 \pm 1 \mathrm{a}$ & Hexanoic acid & $614 \pm 93 b$ & $1 \_349 \pm 17 \mathrm{a}$ \\
\hline 1-Octanol & $51 \pm 1 \mathrm{a}$ & $23 \pm 0 \mathrm{~b}$ & Octanoic acid & $429 \pm 15 b$ & $2273 \pm 90 \mathrm{a}$ \\
\hline 3-Methyl-1-propanol & $30 \pm 1 b$ & $154 \pm 10 \mathrm{a}$ & Decanoic acid & $157 \pm 31 b$ & $1 \_121 \pm 113 a$ \\
\hline Benzyl alcohol & $119 \pm 20 \mathrm{a}$ & $91 \pm 15 a$ & Total & $1200 \pm 70$ & $4743 \pm 178$ \\
\hline 2-Phenylethanol & $14256 \pm 978 b$ & $22696 \pm 2399 a$ & & & \\
\hline \multirow[t]{2}{*}{ Total } & $62318 \pm 4164$ & $78858 \pm 4348$ & Lactones & & \\
\hline & & & $\gamma$-Butyrolactone & $128 \pm 13 \mathrm{a}$ & $42 \pm 6 b$ \\
\hline Esters & & & Dihydro-5-pentyl-2(3H)-furanone & $241 \pm 12 \mathrm{a}$ & $36 \pm 1 b$ \\
\hline Ethyl 2 -methylpropanoate & $10 \pm 1 \mathrm{a}$ & $\mathrm{NPb}$ & Total & $369 \pm 10$ & $78 \pm 6$ \\
\hline Ethyl butanoate & $148 \pm 11 \mathrm{a}$ & $\mathrm{NPb}$ & & & \\
\hline Ethyl 2-methylbutanoate & $\operatorname{Tr}$ & NP & Volatile phenols & & \\
\hline Ethyl 3-methylbutanoate & $\operatorname{Tr}$ & NP & 4-Vinyl guaiacol & $61 \pm 4 b$ & $101 \pm 11 \mathrm{a}$ \\
\hline 3-Methylbutyl acetate & $178 \pm 1 b$ & $522 \pm 54 \mathrm{a}$ & Total & $61 \pm 4$ & $101 \pm 11$ \\
\hline Ethyl hexanoate & $206 \pm 3 b$ & $420 \pm 18 \mathrm{a}$ & & & \\
\hline Ethyl heptanoate & $16 \pm 1 \mathrm{a}$ & Trb & Aldehydes & & \\
\hline Ethyl lactate & $226 \pm 3 b$ & $600 \pm 31 \mathrm{a}$ & Benzaldehyde & $240 \pm 4 a$ & $\mathrm{NPb}$ \\
\hline Ethyl octanoate & $161 \pm 9 b$ & $727 \pm 10 \mathrm{a}$ & Total & $240 \pm 4$ & \\
\hline Ethyl decanoate & $63 \pm 12 b$ & $389 \pm 14 a$ & & & \\
\hline Diethyl succinate & $1192 \pm 163 b$ & $2149 \pm 16 a$ & Others & & \\
\hline Ethyl vanillate & $106 \pm 14 \mathrm{a}$ & $34 \pm 5 b$ & N-3-Methylbutil acetamide & $510 \pm 49 a$ & $83 \pm 14 b$ \\
\hline 2-Phenylethyl acetate & $21 \pm 2 b$ & $78 \pm 4 a$ & Total & $510 \pm 49$ & $83 \pm 14$ \\
\hline Total & $2327 \pm 187$ & $5099 \pm 85$ & & & \\
\hline
\end{tabular}

NP, Tr Not present, traces.

* Data followed by different letters within each compound are significantly different at $\mathrm{P}<0.01$.

to a lesser extent, in Moscato bianco grapes (Mazza et al., 2003). To our knowledge, this is the first time that geranic acid has been found at a higher concentration than linalool, which generally is the most abundant terpene compound. The terpenoid composition of MS is quantitatively and qualitatively different from that reported by Selli et al. (2003) on Muscat of Bornova, and quantitatively was more similar to Muscat, "a petit grain" vintage 2002 wine studied by Sánchez Palomo et al. (2007). In fact, we found higher amounts of geranic acid, linalool, $\beta$-citronellol, nerol and geraniol in comparison to that in Muscat of Bornova wine. Moreover, the terpenoid content of MS, in general, was higher than that in aromatic wines other than Muscat (Versini et al., 2000). The concentration of linalool, geraniol and $\beta$-citronellol in MS was higher than their OTV (see Table 2) (Etievant, 1991; Guth, 1997; Ferreira et al., 2000). From the analysis of terpenoids it is possible to clearly differentiate the MS from the MV wine. The MV terpenoid content, on the other hand, was higher than that reported in other Malvasia wines (Camara et al., 2004; Muratore et al., 2007). Moreover, in a previous study on Malvasia of Bosa grapes cultivated in the North of Italy, the terpenoid concentration was found to be very low and the authors did not reveal it (Borsa et al., 2005).

Regarding the fermentative compounds, the main compounds in both wines were the alcohols 3 and 2-methyl- 


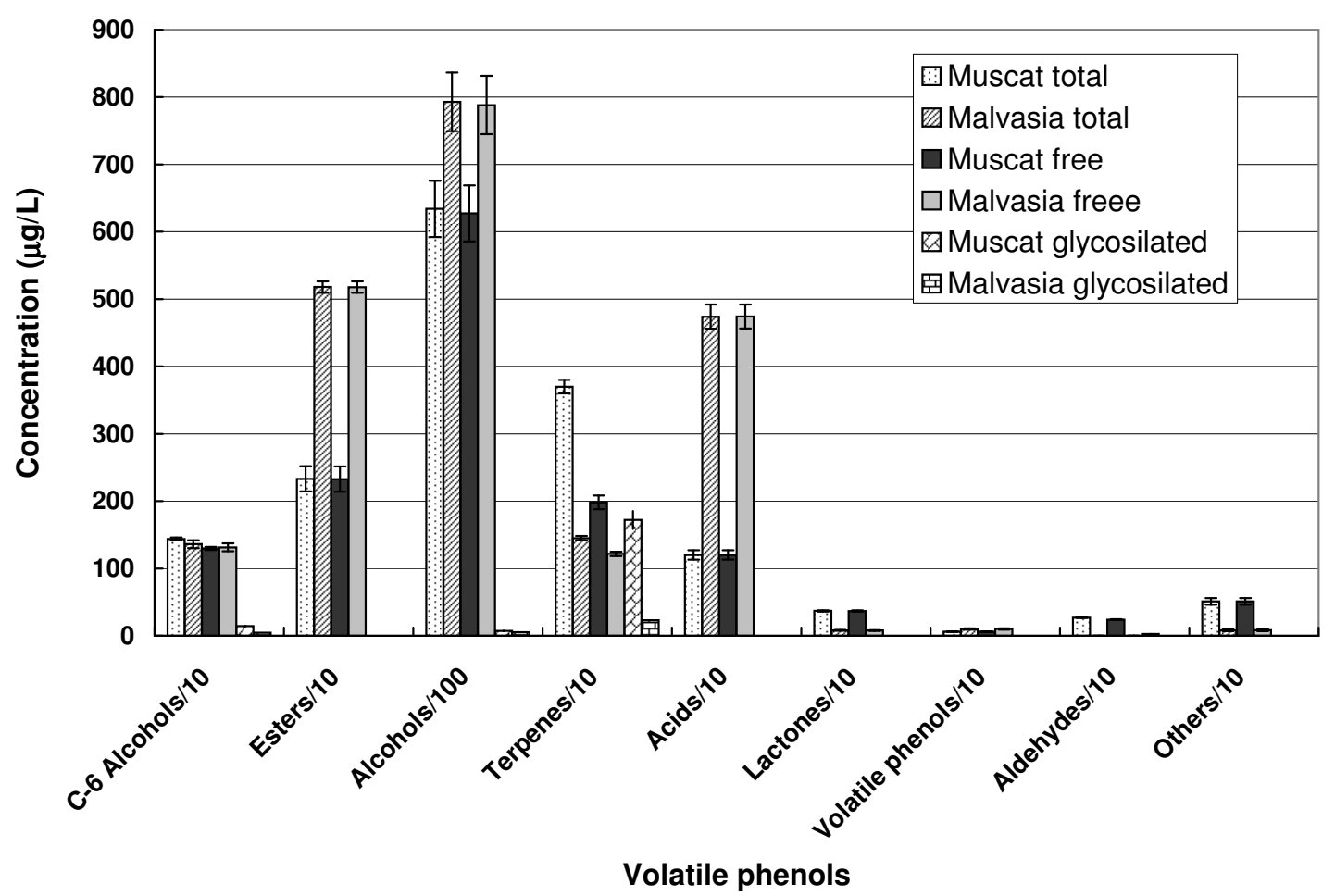

FIGURE 1

Mean and standard deviation of total, free and glycosylated volatile compound classes detected in Muscat of Sorso-Sennori and Malvasia di Bosa sweet wines.

1-butanol, and 2-phenylethanol. Similar amounts of these compounds have been found in Muscat of Bornova (Selli et al., 2006), while Muratore et al. (2007) found higher amounts in Malvasia delle Lipari wines. This class of compounds has a positive effect on the aromatic quality of wine when the concentration is not more than $300 \mathrm{mg} / \mathrm{L}$ (Rapp \& Versini, 1996), while concentrations higher than $400 \mathrm{mg} / \mathrm{L}$ may act negatively (Mateo et al., 2001). In both wines we found a total amount less than $300 \mathrm{mg} / \mathrm{L}$ (Table 1). We have to highlight the presence of 2-phenylethanol, characterised by a pleasant rose aroma (Swiegers \& Pretorius, 2005), which ranged from 14.2 to $22.6 \mathrm{mg} / \mathrm{L}$ in the MS and MV respectively, thus concentrations slightly higher than the OTV (Table 2) (Ferreira et al., 2000). The level of 2-phenylethanol has been reported to be related both to grape variety and yeast metabolism (Gomez-Plaza et al., 1999). MS wine has a higher content than MV of 1-octen-3-ol, which may confer a mushroom odour that is a by-product of the metabolic activity of Botrytis cinerea (Yunome et al., 1981). C-6 alcohols that derive from lipoxygenase activity and that are unfavourable to wine quality, due to the fact that they convey herbaceous and leafy notes (Joslin \& Ough, 1978), were found in very low amounts, and 1-hexanol was the most abundant in both wines. All C-6 alcohols were found in lower amounts with respect to their OTV (Etievant, 1991).

Esters, which contribute to the fruity flavour of young wines, were observed at lower levels than those reported in Muscat of Bornova (Selli et al., 2006) and Muscat of Alexandria (Cabaroglu et al., 2002). We found mainly ethyl fatty acid esters, also thanks to fermentation conducted at a low temperature (Molina et al., 2007), and two acetates. Ethyl fatty acid esters provide a sweet and/or soap odour to wine (Etievant, 1991). Some of them have a very low OTV
(Ferreira et al., 2000), thus both wines and, in particular the Malvasia wine, can be characterised by ethyl hexanoate (green apple flavour), which has a calculated OAV of 84, and by ethyl octanoate (sweet, soap), with an OAV of 363.5 (Table 2). Muscat can be also characterised by ethyl butanoate, which was not found in Malvasia. Diethyl succinate, which gives a sweet, fruity flavour, was the most abundant ester in both wines. MV has a higher content of esters than MS, in particular of ethyl lactate, ethyl octanoate and 3-methylbutyl acetate. Ester development depends on amino acid metabolism, thus the higher content in MV may be due to a different amino-acidic composition of the must, which in turn depends on grape composition, yeast density and environmental conditions (Spranger et al., 2004).

Volatile acids, which are yeast by-products in the form of long-chain fatty acids, were found in higher amount in the MV wine. In particular, we detected hexanoic, octanoic and decanoic acids. These C6 to C10 fatty acids may impart mild and pleasant aromas to wine when found at concentrations of 4 to $10 \mathrm{mg} / \mathrm{L}$ (Shinohara, 1985). The ferulic acid deriving phenol, 4-vinyl guaiacol, was the unique volatile phenol detected in both wines. This compound has been reported to play an important role in white wines, as reported in the case of Gewürztraminer wine from the north of Italy (Versini, 1985). In general it has a negative effect on wine aroma, but in our case its level was much lower than the reported OTV (Ferreira et al., 2000). Among the carbonyl compounds we found very low levels of two lactones, $\gamma$-butyrolactone and dihydro-5-pentyl-2(3H)-furanone, and of benzaldehyde. The $\gamma$-butyrolactone can be found in every fermented product and may occur through chemical or enzymatic formation, presumably from glutamic acid (Wurz et al., 1988). 


\section{Bound volatile compounds}

A total of 26 volatile compounds, one only in traces, were found in the MS and MV wines (Table 3; Fig. 1). We detected three $C-6$ alcohols, nine higher alcohols, 13 terpenes and two aldehydes. Bound compounds are flavourless precursor compounds, thus are a reservoir of flavour. MS was characterised by a high content of all bound volatiles in comparison to MV. The terpenes in MS accounted for $45.5 \%$ of the total bound volatiles, while in MV there were only $15.7 \%$. In particular, bound nerol and geraniol were present at more than twice the concentration of the free fraction in MS, and this confirm the results found for Muscat of Alexandria (Gunata et al., 1986; Selli et al., 2003). MS can be differentiated clearly from MV on the basis of its higher content of terpenes and the absence of terpinen 4-ol, 2,6-dimethyl-3,7-octadien-2,6-diol and 2,6-dimethyl1,7-octadien-3,6-diol, while MV completely lacked any trans and cis linalool oxides and epoxylinalool I. Bound C-6 alcohols and higher alcohols were at a very low level. 2-Phenylethanol was the main bound alcohol in both wines. We found two aldehydes, namely benzaldehyde and neral, but only in MS

\section{CONCLUSIONS}

In the present work, aroma compounds of sweet wines obtained from Muscat and Malvasia grown in two specific regions of Sardinia were characterised for the first time and can be very helpful to the producers. Varietal and fermentative aroma compounds were identified and quantified in the free and glycosylated form. A total of 52

TABLE 2

Odour activity values (OAVs) of volatile compounds with more influence on the aroma of Muscat of Sorso-Sennori and Malvasia di Bosa wines.

\begin{tabular}{|c|c|c|c|c|}
\hline Compounds & Sensory descriptor & Odour threshold $(\mu \mathrm{g} / \mathrm{L})$ & Muscat & Malvasia \\
\hline Linalool & Flowery & $15^{\mathrm{a}}$ & 21.73 & 2.8 \\
\hline Geraniol & Citric & $30^{\mathrm{a}}$ & 7.63 & $\mathrm{UT}^{*}$ \\
\hline 2-Phenylethanol & Roses, sweet & $10000^{\mathrm{a}}$ & 1.42 & 2.27 \\
\hline Terpinen 4-ol & Flowery & $15^{\mathrm{d}}$ & UT & 39.93 \\
\hline$\beta$-Citronellol & Lemon, lime & $100^{\mathrm{a}}$ & 1.85 & UT \\
\hline 3-Methylbutyl acetate & Banana & $2^{\mathrm{c}}$ & 89 & 261 \\
\hline Ethyl butanoate & Kiwi & 20 & 7.4 & - \\
\hline Ethyl hexanoate & Fruity, green, apple, banana & $5^{\mathrm{a}}$ & 41.2 & 84 \\
\hline Ethyl octanoate & Fruity, banana, pineapple, peach, sweet & $2^{\mathrm{a}}$ & 80.5 & 363.5 \\
\hline Ethyl decanoate & Sweet, grass & $200^{\mathrm{b}}$ & UT & 1.95 \\
\hline Hexanoic acid & Cheese & $300^{\mathrm{a}}$ & 2.05 & 4.50 \\
\hline Octanoic acid & Grass acid & $500^{\mathrm{b}}$ & UT & 4.55 \\
\hline
\end{tabular}

${ }^{a}$ Guth (1997)

${ }^{\mathrm{b}}$ Ferreira et al. (2000)

${ }^{\mathrm{c}}$ Takeoka et al. (1989)

d Vilanova et al. (2006)

* Below threshold

\section{TABLE 3}

Bound volatiles $(\mu \mathrm{g} / \mathrm{L} \pm \mathrm{SD})$ detected in Muscat of Sorso-Sennori and Malvasia di Bosa sweet wines.

\begin{tabular}{lcc}
\hline Volatile Compounds & Wine & Malvasia \\
\hline C-6 Alcohols & & MPscat \\
1-Hexanol & $121.8 \pm 2.8 \mathrm{a}^{*}$ & $13.9 \pm 0.7 \mathrm{a}$ \\
(E)-2- Hexen-1-ol & $16.7 \pm 0.5 \mathrm{a}$ & $30.6 \pm 1.9 \mathrm{a}$ \\
(E)-3 Hexen-1-ol & $3.8 \pm 0.5 \mathrm{~b}$ & $\mathbf{4 4 . 5} \pm \mathbf{2}$ \\
Total & $\mathbf{1 4 2 . 3} \pm \mathbf{3}$ & $9.5 \pm 1.1 \mathrm{a}$ \\
& & $38.5 \pm 4.0 \mathrm{a}$ \\
Alcohols & & $134.8 \pm 2.5 \mathrm{a}$ \\
2-Methyl-1-propanol & $6.3 \pm 0.9 \mathrm{a}$ & $44.2 \pm 4.1 \mathrm{a}$ \\
1-Butanol & $16.6 \pm 2.0 \mathrm{~b}$ & $10.7 \pm 0.8 \mathrm{a}$ \\
3-Methyl-1-butanol & $176.0 \pm 17.6 \mathrm{a}$ & $12.9 \pm 0.4 \mathrm{a}$ \\
1-Pentanol & $27.7 \pm 2.1 \mathrm{~b}$ & $\mathrm{NPb}$ \\
1-Octen-3-ol & $10.4 \pm 1.4 \mathrm{a}$ & $109.2 \pm 7.5 \mathrm{~b}$ \\
1-Heptanol & $11.8 \pm 1 \mathrm{a}$ & $169.6 \pm 10.4 \mathrm{~b}$ \\
1-Octanol & $5.0 \pm 0.6 \mathrm{a}$ & $\mathbf{5 2 9 . 4} \pm \mathbf{2 0}$ \\
Benzyl alcohol & $182.7 \pm 16.2 \mathrm{a}$ & $287.2 \pm 27.0 \mathrm{a}$ \\
2-Phenylethanol & $\mathbf{7 2 3 . 7} \pm \mathbf{3 7}$ & \\
Total & & \\
\hline
\end{tabular}




\begin{tabular}{lcc}
\hline Volatile Compounds & Wine & Malvasia \\
\hline Terpenes & Muscat & $\mathrm{NPb}$ \\
(E) Linalool oxide & & $\mathrm{NPb}$ \\
(Z) Linalool oxide & $19.2 \pm 3.5 \mathrm{a}$ & $33.7 \pm 5.1 \mathrm{~b}$ \\
Linalool & $58.5 \pm 11.8 \mathrm{a}$ & $35.0 \pm 3.8 \mathrm{a}$ \\
Terpinen 4-ol & $307.4 \pm 35.2 \mathrm{a}$ & $\mathrm{NP}$ \\
Hotrienol & $\mathrm{NPb}$ & $2.9 \pm 0.3 \mathrm{~b}$ \\
$\alpha$-Terpineol & $\mathrm{Tr}$ & $27.3 \pm 4.4 \mathrm{a}$ \\
2,6-Dimethyl-3,7-octadien-2,6-diol & $22.5 \pm 3.1 \mathrm{a}$ & $\mathrm{NPb}$ \\
Epoxylinalool I Epossilinaloolo I & $\mathrm{NPb}$ & $48.8 \pm 6.9 \mathrm{a}$ \\
Epoxylinalool II & $120.2 \pm 22.6 \mathrm{a}$ & trb \\
$\beta$-Citronellol & $9.2 \pm 2.0 \mathrm{~b}$ & $5.6 \pm 0.7 \mathrm{~b}$ \\
Nerol & $26.6 \pm 1.9 \mathrm{a}$ & $33.6 \pm 1.0 \mathrm{~b}$ \\
Geraniol & $570.4 \pm 54.3 \mathrm{a}$ & $41.8 \pm 3.7 \mathrm{a}$ \\
2,6-Dimethyl-1,7-octadien-3,6-diol & $589.1 \pm 44.3 \mathrm{a}$ & $\mathbf{2 2 9 . 0} \pm \mathbf{2 6}$ \\
Totals & $\mathrm{NPb}$ & $\mathrm{NPb}$ \\
Aldehydes & $\mathbf{1 7 2 3 . 1} \pm \mathbf{1 3 4}$ & $\mathrm{NPb}$ \\
Benzaldehyde & & $\mathbf{2 4 . 6} \pm \mathbf{2}$ \\
Neral & & \\
Totals & $12.1 \pm 2.0 \mathrm{a}$ & \\
\hline
\end{tabular}

NP Not present

* Data followed by different letters within each compound are significantly different at $\mathrm{P}<0.01$.

free and 26 bound volatile compounds were identified and quantified. MS has a higher content of both free and bound terpenes in comparison to MV wine, which was richer in free esters and acids. Bound compounds were present in greater quantities in MS.

According to their OAVs, 3-methylbutyl acetate, ethyl octanoate, ethyl hexanoate and linalool were the main characteristic aroma-active compounds of Muscat wine. Malvasia wine, on the other hand, was characterised particularly by ethyl octanoate, which may confer fruity, banana, pineapple, peach and sweet notes, and by 3-methylbutyl acetate, which may give banana flavour.

\section{LITERATURE CITED}

Borsa, D., Carniel, D., Asproudi, A., Ponticelli, L., Crespan, M. \& Costacurta, A., 2005. Caratterizzazione di uve malvasia attraverso lo studio dei metaboliti secondari. Atti I Convegno "Le Malvasie del bacino del mediterraneo" Porec (Croatia), 19-21 maggio 2005. Riv. Vitic. Enol. 2-3-4, 167-182.

Bureau, S.M., Razungles, A.L. \& Baumes, R.L., 2000. The aroma of Muscat of Frontignan grapes: effect of the light environment of vine or bunch on volatiles and glycoconjugates. J. Sci. Food Agr. 80, 2012-2020.

Cabaroglu, T., Canbas, A., Lepoudre, J.P. \& Gunata, Z., 2002. Free and bound compound volatile composition of red wines of Vitis vinifera L. cv. Okuzgozu and Bogazkere grown in Turkey. Am. J. Enol. Vitic. 51, 64-68.

Camara, J.S., Herbert, P., Marques, J.C. \& Alves, M.A., 2004. Varietal flavour compounds of four grape varieties producing Madeira wines. Anal. Chim. Acta 513, 203-207.

Croser B., 1989. Botrytis affected wines. Aust. NZ. Wine Ind. J. 4(3), $155-$ 158.

Di Stefano, R., 1991. Proposal for a method of sample preparation for the determination of free and glycoside terpenes of grapes and wines. B. O. I. V. 721-722, 219-223.
Di Stefano, R., Gentilini, N. \& Ummarino, I. 2000. Studio dei profili aromatici di varietà a frutto bianco coltivate nella zona del Collio. L'Enologo 38, 95-102.

Etievant, P.X., 1991. Wine. In: Maarse, H. (ed). Volatile compounds in food and beverages. Marcel Dekker. Inc., New York. pp. 483 - 546.

Ferreira, V., Lopez, R. \& Cacho, J.F., 2000. Quantitative determination of the odorants of young red wines from different grape varieties. J. Sci. Food Agr. 80, 1659-1667.

Fischer, U., Rothb, D. \& Christmann, M., 1999. The impact of geographic origin, vintage and wine estate on sensory properties of Vitis vinifera cv. Riesling wines. Food Qual. Prefer. 10, 281-288.

Gomez-Plaza, E., Gil-Muňoz, R., Carrero-Espin, J., Fernandez-Lopez J.A \& Martinez-Cutillas, A., 1999. Investigation on the aroma of wines from seven clones of Monastrell grapes. Eur. Food Res. Technol. 209, 257-260.

Gunata, Y.Z, Bayonove, C.L., Baumes, R.L. \& Cordonnier, R.E., 1986. Stability of free and bound fractions of some aroma components of grapes cv. Muscat during the wine processing. preliminary results. Am. J. Enol. Vitic. 29, 11-17.

Guth, H., 1997. Quantitation and sensory studies of character impact odorants of different white varieties. J. Agric. Food Chem. 45, 3027-3032.

Joslin, W.S. \& Ough, C.S., 1978. Cause and fate of certain C6 compounds formed enzymatically in macerated grape leaves during harvest and wine fermentation. Am. J. Enol. Vitic. 37, 112-114.

Kotseridis, Y., Baumes, R. \& Skouroumounis, G.K., 1998. Synthesis of labelled $\left[{ }^{2} \mathrm{H}_{4}\right]-\beta$ - damascenone, $\left[{ }^{2} \mathrm{H}_{2}\right]$-2-methoxy-3-isobutylpyrazine, $\left[{ }^{2} \mathrm{H}_{2}\right]$ $\alpha$-ionine, and $\left[{ }^{2} \mathrm{H}_{3}\right]-\beta$-ionine, for quantification in grapes, juices and wines. J. Chromatogr. A 824, 71-78.

Marais, J., 1983. Terpenes in the aroma of grapes and wines. a review. S. Afr. J. Enol. Vitic. 4, 49-58.

Mateo, J.J., Gentilini, N., Huerta, T., Jimenez, M. \& Di Stefano, R., 1997. Fractionation of glycoside precursors of aroma in grape and wine. J. Chromatogr. A 778, 219-224.

Mateo, J.J., Jimeniz, M., Pastor, A. \& Huerta, T., 2001. Yeast starter cultures affecting fermentation and volatiles. Food Res. Int. 34, 307-314. 
Mazza, G., Cascio, P. \& Barbieri, E., 2003. Composti volatili liberi e glicoconiugati presenti nelle foglie e negli acini della Vitis vinifera cv. Moscato bianco. Riv. Vitic. Enol. 56(2-3), 57-74.

Moio, L., Ugliano, M., Gambuti, A., Genovese, A. \& Piombino, P., 2004. Influence of clarification treatments on the concentrations of selected free varietal aroma compounds and glycoconjugates in Falanghina (Vitis vinifera L.) must and wine. Am. J. Enol. Vitic. 55(1), 7-12.

Molina, A.M., Swiegers, J.H., Varela, C., Pretorius, I.S. \& Agosin, E., 2007. Influence of wine fermentation temperature on the synthesis of yeastderived volatile aroma compounds. Appl. Microbiol. Biot. 77, 675-687.

Muratore, G., Nicolosi Asmundo, C., Lanza, C.M., Caggia, C., Licciardello, F. \& Restuccia, C., 2007. Influence of Saccharomyces uvarum on volatile acidity, aromatic and sensory profile of Malvasia delle Lipari wine. Food Technol. Biotechnol. 45, 101-106.

Pisarnitskii, A.F., 2001. Formation of wine aroma. tones and imperfections caused by minor components (review). Appl. Biochem. Microb. 37(6), 552560.

Rapp, A. \& Versini, G., 1996. Volatile phenolic compounds in wine. Deut. Lebensm-Rundsch 92(2), 42-48.

Rapp, A., Mandery, H. \& Niebergall, H., 1986. New monoterpendiols in grape must and wine and in cultures of Botrytis cinerea. Vitis 25, 79-84.

Sánchez Palomo, E., Díaz-Maroto, M.C., González Viñas M.A., SorianoPérez, A. \& Pérez-Coello, M.S., 2007. Aroma profile of wines from Albillo and Muscat grape varieties at different stages of ripening. Food Control 18, 398-403.

Sefton, M.A., Francis, I.L. \& Williams, P.J., 1993. The volatile composition of Chardonnay juice. A study by flavor precursor analysis. Am. J. Enol. Vitic. 44, 358-370.

Selli S., Cabaroglu T., Canbas A., Erten H. \& Nurgel C., 2003. Effect of skin contact on the aroma composition of the musts of Vitis vinifera L. cv. Muscat of Bornova and Narince grown in Turkey. Food Chem. 81, 341-347.

Selli, S., Canbas, A., Cabaroglu, T., Erten, H. \& Gunata, Z., 2006. Aroma components of cv. Muscat of Bornova wines and influence of skin contact treatment. Food Chem. 94, 319-326.
Shinohara, T., 1985. Gas chromatographic analysis of volatile fatty acids in wines. Agr. Biol. Chem. Tokio 49, 2211-2212.

Spranger, M.I., Clımaco, M.C., Sun, B. Eiriz, N., Fortunato, C., Nunes, A., Leandro, M.C., Avelar, M.L. \& Belchior, A.P., 2004. Differentiation of red winemaking technologies by phenolic and volatile composition. Anal. Chim. Acta 513, 151-161.

Swiegers, J.H. \& Pretorius, I.S., 2005. Yeast modulation of wine flavour. Adv. Appl. Microbiol. 57, 131-175.

Takeoka, G., Buttery, R.G., Flath, A., Terahishi, R., Wheeler, E.L. Wieczorek, L. \& Guetert, M., 1989. Volatile constituents of pineapple. In: Teranishi, R., Buttery, R.G. \& Shahidi, F. (eds). Flavor chemistry: trends and development. ACS Symposium Series, Washington DC. pp. $221-237$.

Versini, G., 1985. On the aroma of Traminer aromatico or Gewuerztraminer wine. Vignevini 12, 57-65.

Vilanova, M. \& Siero, C., 2006. Determination of free and bound terpene compounds in Albariño wine. J. Food Compos. Anal. 19, 694-697.

Vilanova, M., Genisheva, Z., Masa, A. \& Oliveira, J.A., 2010. Correlation between volatile composition and sensory properties in Spanish Albariño wines. Microchem. J. 95, 240-246.

Winterhalter, P., 1993. The generation of C13-norisoprenoid volatiles in Riesling wine. In: Crouzet, J., Flanzy, C. Martin, C. \& Sapis J.C. (eds) Connaissance aromatique des cepages et qualite des vins. Montpellier, Revue Francaise d'Oenologie. pp. $65-73$.

Wurz, R.E.M., Kepner, R.E. \& Webb, A.D., 1988. The biosynthesis of certain gamma-lactones from glutamic acid by film yeast activity on the surface of flor sherry. Am. J. Enol. Vitic. 39, 234-238.

Yunome, H., Zenibayashi, Y. \& Date, M., 1981. Characteristic components of botrytised wine, sugar, alcohols, organic acids, and other factors. Hakkokogaku Kaishi 59, 169-175.

Zalacain, A., Marın, J., Alonso, G.L. \& Salinas, M.R., 2007. Analysis of wine primary aroma compounds by stir bar sorptive extraction. Talanta 71, 1610-1615. 